Vol. 11 (2002): 355-369.

\title{
Nitrogen and phosphorus losses from a feedlot for suckler cows
}

\author{
Jaana Uusi-Kämppä \\ MTT Agrifood Research Finland, Environmental Research, FIN-31600 Jokioinen, Finland, \\ e-mail: jaana.uusi-kamppa@mtt.fi
}

\begin{abstract}
The raising of cattle outdoors in winter is becoming more common in temperate areas, although there is little information available on the effects of this practice on forested environments. In this study, the concentrations of ammonium acetate extractable phosphorus $\left(\mathrm{P}_{\text {AAAc }}\right)$ and mineral nitrogen $\left(\mathrm{NH}_{4}-\mathrm{N}\right.$ and $\mathrm{NO}_{3}-\mathrm{N}$ ) in soil and the quality of percolation water from an open feedlot were studied in eastern Finland in 1997-2000. In each of four pens $\left(975-1300 \mathrm{~m}^{2}\right)$ eight suckler cows were fed in winter from 1995 in the case of the first two pens and from 1996 in the remaining two. The suckler cows usually stayed in the front part of the feedlot. Therefore the nutrient loading was also the highest in this part of the lot. When the pens had been used for 1-2 winters, the mean contents of $\mathrm{P}_{\text {AAAc }}, \mathrm{NH}_{4}-\mathrm{N}$ and $\mathrm{NO}_{3}-\mathrm{N}$ in the surface soil $(0-5 \mathrm{~cm})$ were 14,73 and $3.0 \mathrm{mg} \mathrm{l}^{-1}$ respectively, compared to only 3.0 , 4.2 and $0.06 \mathrm{mg} \mathrm{l}^{-1}$ in the control forested area. In the front part of a 1-m-deep soil layer, the mean amounts of $\mathrm{NH}_{4}-\mathrm{N}$, and $\mathrm{NO}_{3}-\mathrm{N}$ were 410 and $28 \mathrm{~kg} \mathrm{ha}^{-1}$ respectively after $1-2$ years of use of the feedlot. In percolation water, too, the mean concentrations of total phosphorus and total nitrogen were high in the front part: $1.7-28$ and $210-1400 \mathrm{mg} \mathrm{l}^{-1}$ respectively. The minimum requirement is cleaning of the dung, and even then loading may be substantial.
\end{abstract}

Key words: Phosphorus, ammonium nitrogen, nitrate nitrogen, feedlots, pens, runoff, leaching, suckler herds

\section{Introduction}

In northern areas, cattle have traditionally been kept indoors in winter due to cold weather and snowfall. However, beef production in feedlots and dairy production systems allowing access to exercise yards are becoming more common in Finland in the winter period as well as other sea- sons. There are several reasons for this. Firstly, legislation governing animal welfare provides that during the summer period dairy cows and heifers must be allowed to go to pasture or, failing this, that a space must be provided in such a way as to allow animals to move around. The transition period ends at the beginning of July 2006. Secondly, a number of consumers are demanding products from organic farms or have a 
Uusi-Kämppä, J. N and P losses from a feedlot for suckler cows

keen interest in aspects of animal welfare, including pastoral production systems or outdoor exercise for cattle. And thirdly, in organic farming all mammals must have access to pasture and an open-air exercise area or an open-air run which may be partially covered (EC 1804/1999). On organic farms, dairy cows are allowed to exercise outdoors in winter as well as other seasons. In addition to the issue of animal welfare, the cost of buildings has encouraged a few farmers in north-western Finland to raise beef animals in extensively forested areas $(0.5$ head per ha) around the year. In future, the environmental risks may increase if large herds are exercised or raised outdoors in small areas.

There is little information available on how to build a good feedlot or exercise yard and on their environmental effects. A feedlot is usually constructed at a fair distance from a barn, and the cattle are fed and kept there for the winter months or all year round. An exercise yard is adjacent to a cow shed, and animals can exercise there daily or weekly for a few hours. According the regulations of the Ministry of the Environment (1998) and the Ministry of Agriculture and Forestry (1999), the surface area of small yards $\left(<20 \mathrm{~m}^{2}\right.$ per animal unit, AU) must be hardened, and polluted waters directed into a well. In large exercise yards ( $\geq 20 \mathrm{~m}^{2}$ per AU) the area in front of the barn doors and the area around feeding facilities must have a dense surface (10-15 $\mathrm{m}^{2}$ per AU or at least $50 \mathrm{~m}^{2}$ per lot).

The Agri-Environmental Scheme for 20002006 limits the number of AU per cultivated field hectare to 2.3 in order to prevent excessive loads of phosphorus and nitrogen compounds from affecting surface and ground waters. In large feedlots with a soil floor the stocking density may be as great as $500 \mathrm{AU} \mathrm{ha}^{-1}$; in such cases 20 $\mathrm{m}^{2}$ per cow is required. Thus the nutrient loading from some feedlot areas may be much higher than in the case of cultivated fields.

In feedlots the manure accumulates on the soil surface. Studies have shown that when excessive amounts of slurry are spread, the nutrient loads, especially phosphorus loads, have dramatically increased (Misselbrook et al. 1995,
Carey et al. 1997). Manure and slurry applications outside the growing season have caused a high risk of nutrient losses to downstream waters (Paul and Zebarth 1997, Turtola and Kemppainen 1998). In addition, outdoor cattle raising in winter months may cause extreme nutrient losses during snow melt (von Wachenfelt 2001). In the UK, Williams et al (2000) estimated that total nitrogen losses from outdoor pig farming systems varied from 264 to $576 \mathrm{~kg} \mathrm{ha}^{-1}$ under different types of management, with 12-25 dry sows per ha.

In many countries, beef cattle are fed in open feedlots, but the climate there differs from Finnish winter conditions. In Finland, snow melt causes runoff of nutrients and faecal micro-organisms from areas treated with slurry (Turtola and Kemppainen 1998, Heinonen-Tanski and Uusi-Kämppä 2001). No environmental studies concerning cattle raising in forested areas in these climatic conditions have been conducted in areas characterised by coarse moraine or peat soil. However, several environmental problems e.g. damage to trees, soil surface compaction and water logging were evident in a feedlot at Tohmajärvi 1995-1996. Therefore an environmental experiment was started in the feedlot in autumn 1997. This paper reports on nitrogen and phosphorus loads from a feedlot with a soil floor in cold weather. The contents of $\mathrm{NH}_{4}-\mathrm{N}, \mathrm{NO}_{3}-\mathrm{N}$ and easily soluble phosphorus in soil of the feedlot were compared to those in adjacent forest. The concentrations of $\mathrm{NH}_{4}-\mathrm{N}, \mathrm{NO}_{3}-\mathrm{N}$, total $\mathrm{N}$, $\mathrm{PO}_{4}-\mathrm{P}$ and total $\mathrm{P}$ in percolation water were measured at the front and rear parts of the pens and outside the feedlot.

\section{Material and methods}

\section{Experimental area}

Four pens for 32 suckler cows were constructed in a forest at the Suckler Cow Unit of the MTT (Fig. 1, Table 1), situated at Tohmajärvi in east- 
Vol. 11 (2002): 355-369.

Fig. 1. Map of the experimental area. Figure by Tapani Kivinen, MTT.

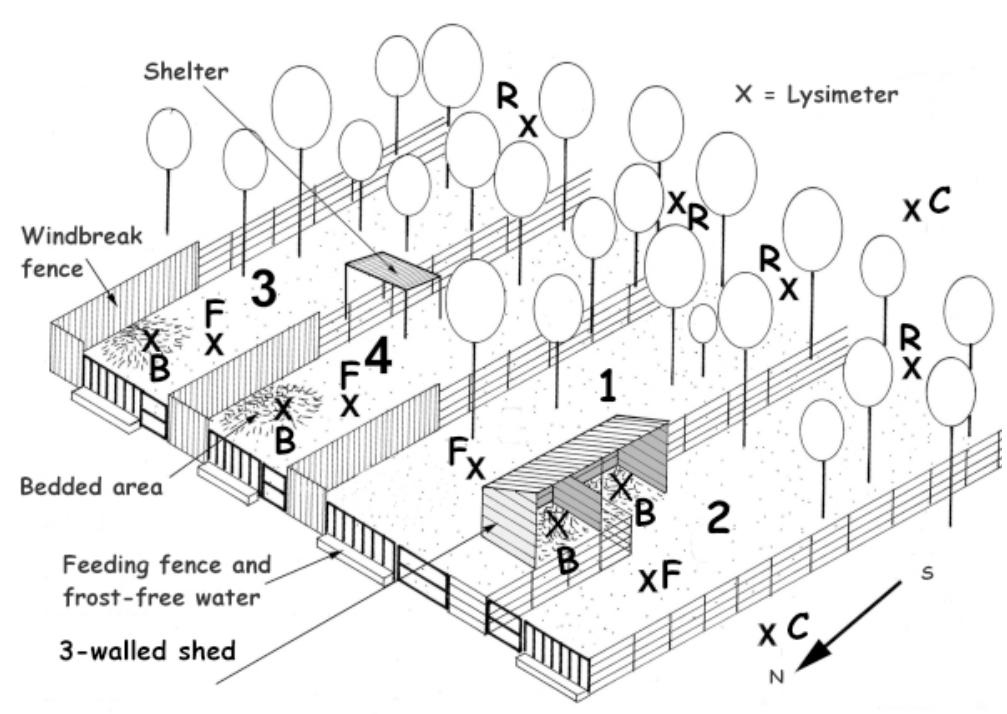

ern Finland $\left(62^{\circ} 14^{\prime} \mathrm{N}, 30^{\circ} 21^{\prime} \mathrm{E}\right)$. The experimental site was even, sloping slightly towards the front of the pens (each $975-1300 \mathrm{~m}^{2}$ ). The soil was loam or sandy loam (Table 2) with a 20$40 \mathrm{~cm}$ thick histic (sapric) epipedon. The soil was tentatively classified as an Aquic Cryortent (Soil Survey Staff 1988) or a Gleyic Dystric Regosol (FAO 1998). The site is a typical forest soil with plenty of moisture, and this facilitates the formation of a histic topsoil. The soil was covered with thick, firm forest vegetation, the trees consisting mainly of middle-aged birch (Betula) and pine species (Pinus), with 400 trunks per ha. The first two pens (numbers 1 and 2) were established in 1995 and the other two (numbers 3 and 4) in 1996 (Manninen 1999). The suckler cows were fed in the feedlot in winter. The cattle spent most of the time at or near the front of the pens, where feeding and bedded areas were located. In March and April the cows calved and spent more time at or near the rear of the feedlot. The cows with calves grazed on a pasture from June to September (Table 3). The soil surface in the front part of feedlot was compacted by the cows. After the rainy summer of 1998 , the surface soil was wet and muddy in the autumn.
Table 1. Size of the pens and animal numbers in each pen during winter 1995-2000.

\begin{tabular}{lcccc}
\hline & Pen 1 & Pen 2 & Pen 3 & Pen 4 \\
\cline { 2 - 5 } Size, $\mathrm{m}^{2}$ & 1300 & $1105^{\text {(a) }}$ & 975 & 975 \\
\cline { 2 - 5 } & \multicolumn{4}{c}{ Animal numbers, head ha ${ }^{-1}$} \\
\hline $1995-1996$ & 62 & 72 & (b) & (b) \\
$1996-1997$ & 62 & 72 & 82 & 82 \\
$1997-1998$ & 54 & 63 & 72 & 72 \\
$1998-1999$ & 62 & $130^{\text {(c) }}$ & 92 & 92 \\
$1999-2000$ & 77 & $180^{\text {(c) }}$ & 82 & 82 \\
\hline
\end{tabular}

(a) $=520 \mathrm{~m}^{2}$ 1998-1999, and $378 \mathrm{~m}^{2}$ 1999-2000

(b) $=$ Not in use 1995-1996

${ }^{(c)}=$ Calves aged under one year

\section{Soil sampling and analyses}

Soil samples were taken to measure nitrogen leaching into deeper soil layers and to analyse phosphorus content in the soil surface. The surface soil was separately sampled in each pen at depths of $0-5,5-10,10-20 \mathrm{~cm}$ in autumn 1997 , 0-10 and 10-20 cm in autumn 1998, and 0-20 $\mathrm{cm}$ in autumn 1999. Deep soil samples were taken at depths of 20-40, 40-60 and 60-100 cm 


\section{Uusi-Kämppä, J. N and P losses from a feedlot for suckler cows}

Table 2. Particle size analysis, $\mathrm{pH}_{(\text {water) }}$, organic carbon and total nitrogen (mean \pm S.D.) in the front and rear of the pens and outside the feedlot in 15 October 1997. Values in parentheses indicate the range.

\begin{tabular}{|c|c|c|c|c|}
\hline \multicolumn{2}{|l|}{$\begin{array}{l}\text { Depth } \\
(\mathrm{cm})\end{array}$} & $\begin{array}{c}\text { Pens 1-4 } \\
\text { Front }\end{array}$ & $\begin{array}{c}\text { Pens 1-4 } \\
\text { Rear }\end{array}$ & Control $^{(\mathrm{c})}$ \\
\hline \multicolumn{4}{|c|}{ Particle size analysis, $\%$} & (a) \\
\hline $10-20$ & $\begin{array}{r}<0.02 \mathrm{~mm} \\
0.02-0.2 \mathrm{~mm} \\
0.2-2.0 \mathrm{~mm}\end{array}$ & (a) & $\begin{aligned} 8 & (7-8)^{(\mathrm{b})} \\
36 & (33-42)^{(\mathrm{b})} \\
56 & (50-61)^{(\mathrm{b})}\end{aligned}$ & $\begin{array}{r}6^{(\mathrm{b})} \\
33^{(\mathrm{b})} \\
61^{(\mathrm{b})}\end{array}$ \\
\hline $20-40$ & $\begin{array}{r}<0.02 \mathrm{~mm} \\
0.02-0.2 \mathrm{~mm} \\
0.2-2.0 \mathrm{~mm}\end{array}$ & (a) & $\begin{aligned} 3 & (0-4) \\
35 & (28-42) \\
62 & (54-72)\end{aligned}$ & $\begin{aligned} 4 & (2-6) \\
35 & (33-37) \\
61 & (58-65)\end{aligned}$ \\
\hline $40-60$ & $\begin{array}{r}<0.02 \mathrm{~mm} \\
0.02-0.2 \mathrm{~mm} \\
0.2-2.0 \mathrm{~mm}\end{array}$ & $\begin{aligned} 5 & (2-8) \\
31 & (15-40) \\
64 & (57-83)\end{aligned}$ & $\begin{aligned} 2 & (0-5) \\
35 & (22-47) \\
63 & (52-78)\end{aligned}$ & $\begin{array}{ll}0 & \\
33 & (26-41) \\
67 & (59-74)\end{array}$ \\
\hline $60-100$ & $\begin{array}{r}<0.02 \mathrm{~mm} \\
0.02-0.2 \mathrm{~mm} \\
0.2-2.0 \mathrm{~mm}\end{array}$ & $\begin{aligned} 3 & (1-8) \\
41 & (25-66) \\
56 & (33-74)\end{aligned}$ & $\begin{array}{cc}0 \\
42 & (14-76) \\
58 & (24-86)\end{array}$ & $\begin{array}{cc}0 \\
30 & (27-32) \\
70 & (68-73)\end{array}$ \\
\hline $\begin{array}{l}\mathrm{pH} \\
0-5 \\
5-10 \\
10-20 \\
20-40 \\
40-60 \\
60-100\end{array}$ & & $\begin{array}{ll}5.3 & (4.6-5.6) \\
5.1 & (4.6-5.8) \\
4.8 & (4.4-5.2) \\
4.7 & (4.5-5.2) \\
4.9 & (4.7-5.3) \\
5.1 & (4.8-5.4)\end{array}$ & $\begin{array}{ll}4.2 & (4.2-4.4) \\
4.0 & (3.9-4.1) \\
4.3 & (4.0-4.5) \\
4.8 & (4.8-5.1) \\
5.0 & (4.7-5.2) \\
5.1 & (4.8-5.4)\end{array}$ & $\begin{array}{ll}3.7 & (3.7-3.7) \\
3.8 & (3.7-3.9) \\
4.2 & (3.7-4.6) \\
4.7 & (4.4-5.0) \\
4.9 & (4.8-5.0) \\
5.2 & (5.1-5.4)\end{array}$ \\
\hline $\begin{array}{l}\text { Organic } \\
0-5 \\
5-10 \\
10-20 \\
20-40 \\
40-60 \\
60-100\end{array}$ & & $\begin{array}{c}21.3 \pm 11.4 \\
20.1 \pm 14.9 \\
21.9 \pm 15.8 \\
21.0 \pm 7.5 \\
3.4 \pm 2.3 \\
1.4 \pm 1.1\end{array}$ & $\begin{array}{c}44.9 \pm 3.2 \\
32.5 \pm 16.5 \\
12.7 \pm 13.6 \\
2.6 \pm 1.4 \\
1.5 \pm 0.6 \\
0.4 \pm 0.2\end{array}$ & $\begin{aligned} 37.1 & (24.0-50.1) \\
32.6 & (8.2-57.0) \\
17.2 & (3.0-31.3) \\
2.8 & (1.5-4.0) \\
1.3 & (0.9-1.7) \\
0.7 & (0.6-0.8)\end{aligned}$ \\
\hline \multicolumn{5}{|c|}{ Total N, \% } \\
\hline $\begin{array}{l}0-5 \\
5-10 \\
10-20 \\
20-40 \\
40-60 \\
60-100\end{array}$ & & $\begin{array}{l}0.85 \pm 0.49 \\
0.78 \pm 0.59 \\
0.83 \pm 0.59 \\
0.74 \pm 0.29 \\
0.11 \pm 0.07 \\
0.04 \pm 0.03\end{array}$ & $\begin{array}{l}1.53 \pm 0.23 \\
1.11 \pm 0.65 \\
0.44 \pm 0.51 \\
0.08 \pm 0.04 \\
0.06 \pm 0.03 \\
0.02 \pm 0.01\end{array}$ & $\begin{array}{ll}1.28 & (0.53-2.03) \\
0.96 & (0.22-1.70) \\
0.47 & (0.10-0.84) \\
0.09 & (0.05-0.12) \\
0.04 & (0.02-0.05) \\
0.02 & (0.02-0.02)\end{array}$ \\
\hline
\end{tabular}

(a) $=$ Particle size analysis not determined in organic soil (organic matter content $>20 \%$ ).

(b) = One sample was organic

(c) $=$ Two replicates

S.D. = Standard deviation

each autumn in the period 1997-1999. Five cores were combined to give one sample for each upper layer: 0-20 and 20-40 cm, and two cores were combined for each of the deeper layers: 4060 and $60-100 \mathrm{~cm}$. The surface samples were taken from the soil layer that was mixed by the 
Vol. 11 (2002): 355-369.

Table 3. Grazing and non-grazing periods in pens and rainfall (mm) in 1997-1998, 1998-1999 and 1999-2000.

\begin{tabular}{|c|c|c|c|}
\hline & $\begin{array}{l}2 \text { June } 1997- \\
31 \text { May } 1998\end{array}$ & $\begin{array}{l}1 \text { June } 1998- \\
31 \text { May } 1999\end{array}$ & $\begin{array}{l}1 \text { June } 1999- \\
31 \text { May } 2000\end{array}$ \\
\hline Grazing period & 2 Jun-26 Oct 1997 & 1 Jun-1 Oct 1998 & 1 Jun-20 Oct 1999 \\
\hline Non-grazing period & $\begin{array}{l}27 \text { Oct } 1997- \\
31 \text { May } 1998\end{array}$ & $\begin{array}{l}2 \text { Oct } 1998- \\
31 \text { May } 1999\end{array}$ & $\begin{array}{l}21 \text { Oct } 1999- \\
31 \text { May } 2000\end{array}$ \\
\hline Rainfall during non-grazing & 340 & 340 & 372 \\
\hline Rainfall during grazing & 321 & 388 & 292 \\
\hline Sum of rainfall & 661 & 728 & 664 \\
\hline
\end{tabular}

cattle. The soil was sampled separately from front and back parts of the pens. In the front parts of the pens, the surface soil with dung was removed after the sampling in autumn of each year. Two control samples were taken from a forest outside the feedlot in autumn 1997. A layer of decomposed moss about $10-15 \mathrm{~cm}$ thick was removed from the soil surface before sampling of the mineral soil in the forest.

Ammonium and nitrate nitrogen from frozen soil samples were analysed following Esala (1991). Easily soluble phosphorus $\left(\mathrm{P}_{\mathrm{AAAc}}\right)$ was extracted using $0.5 \mathrm{M} \mathrm{NH}_{4}$-acetate $-0.5 \mathrm{M}$ acetic acid at pH 4.65 (Vuorinen and Mäkitie 1955) which is the method used for soil testing in Finland. The density of ground soil was determined by weighing a $25 \mathrm{ml}$ scoop of air-dry soil (Vuorinen and Mäkitie 1955, Tares and Sippola 1978). The $\mathrm{pH}$ value was taken from a soil-water suspension (1:2.5) following Vuorinen and Mäkitie (1955). Total nitrogen (TN) was determined by using a C-N-autoanalyser (LECO).

\section{Water sampling and analyses}

Nutrient leaching was assessed using percolation lysimeters (Derome et al. 1991). The lysimeter included a 2-litre polyethylene bottle and a plastic funnel (diameter $200 \mathrm{~mm}$ ). The funnel was filled with acid washed quartz sand (diameter $0.5-1.5 \mathrm{~mm}$ ). The percolation water was removed from the lysimeter by means of a suction pump and passed through a plastic tube into a collection bottle, after water had flowed into the lysimeter bottle. Because of the poor water flow to the lysimeter bottles, the water was sampled only eight times during the 2.5-year experiment. The volume of the percolation water was measured, and the water samples were stored in polyethylene bottles in a freezer before analyses.

Percolation lysimeters were installed at a depth of 30-40 cm near the front and the rear of each pen in October 1997 (Fig. 1). Two control lysimeters were installed in an adjacent forest. In autumn 1998, lysimeters were installed under the bedded areas for cattle. At the front of the feedlot, the lysimeters worked for one or two years only; therefore four new units were installed in the front part in autumn 1999.

Water samples were also taken from a ditch adjacent to the feedlot in 1998. The ditch water contained drainage and surface runoff water from the whole feedlot area, and the water was stored in a small pond. The water volumes were measured and pot samples taken while the water was being pumped from the pond in 1998 .

Concentrations of total nitrogen (TN) and total phosphorus (TP) were determined in unfiltered water samples. For other determinations, water samples were filtered through a membrane filter (Nuclepore ${ }^{\circledR}$, Polycarbonate, pore size $0.2 \mu \mathrm{m}$ ) before analyses. The samples for ammonium nitrogen $\left(\mathrm{NH}_{4}-\mathrm{N}\right)$ and nitrate nitrogen $\left(\mathrm{NO}_{3}-\mathrm{N}\right)$ were analysed by means of a Skalar autoanalyser according to the Finnish standard methods (SFS 3030, SFS 3032). TN was determined by oxidation of nitrogen compounds to nitrate in alkaline solution (SFS 3031). Orthophosphate phosphorus $\left(\mathrm{PO}_{4}-\mathrm{P}\right)$ was determined 
by means of a molybdate blue method, using ascorbic acid as the reducing agent (Murphy and Riley 1962, SFS 3025). The concentration of TP was measured from a sample which was digested with peroxodisulphate in an autoclave (SFS 3026). $\mathrm{PO}_{4}-\mathrm{P}, \mathrm{TP}$ and $\mathrm{TN}$ were determined by using the FIAstar autoanalyser.

Flow-weighted mean nutrient concentration $\left(\mathrm{c}_{\mathrm{fwm}}\right)$ in percolation water was calculated according to the formulas (1), (1a) and (1b):

$$
c_{\mathrm{fwm}}=\frac{\mathrm{m}_{1}}{\mathrm{~V}_{1}}
$$

where

(1a) $\mathrm{m}_{1}=\sum_{\mathrm{i}=1}^{n}\left(\mathrm{c}_{i} \mathrm{~V}_{i}\right)$ and

$$
\mathrm{V}_{1}=\sum_{\mathrm{i}=1}^{n}\left(\mathrm{~V}_{i}\right)
$$

where

$\mathrm{m}_{1}=$ nutrient mass in the lysimeters $(\mathrm{mg})$

$\mathrm{c}_{i}=$ nutrient concentration in a sample $\left(\mathrm{mg} \mathrm{l}^{-1}\right)$

$\mathrm{V}_{i}=$ water volume in a lysimeter (1)

$\mathrm{V}_{1}=$ water volume in the lysimeters (1)

The nutrient mass in percololation water was calculated according the formula (2):

$$
\mathrm{m}_{2}=\frac{\mathrm{m}_{1}}{100 \mathrm{n}\left(\Pi \mathrm{r}^{2}\right)}
$$

$\mathrm{m}_{2}=$ leached nutrient load per hectare $\left(\mathrm{kg} \mathrm{ha}^{-1}\right)$

$\mathrm{m}_{1}=$ nutrient mass in the lysimeters $(\mathrm{mg})$

$\mathrm{n}$ = number of lysimeters

$\mathrm{P}=$ pi (3.1415926)

$\mathrm{r}=$ radius of the funnel $(0.1 \mathrm{~m})$

The standard deviation was calculated according to the formula (3):

$$
\mathrm{s}^{2}=\frac{\sum_{i=1}^{n}\left(\mathrm{x}_{i}-\mathrm{x}\right)^{2}}{(\mathrm{n}-1)} \text { where }
$$

$\mathrm{s}=$ standard deviation

$\mathrm{x}=$ arithmetic mean

$\mathrm{x}_{i}=$ value of a sample

$\mathrm{n}=$ number of samples

\section{Results}

\section{Mineral nitrogen in soil}

The amount of mineral nitrogen $\left(\mathrm{NH}_{4}-\mathrm{N}+\right.$ $\mathrm{NO}_{3}-\mathrm{N}$ ) in the soil was high in pens 1 and 2 after two seasons of outdoor raising, and after one season in pens 3 and 4 in autumn 1997 (Fig. 2). The proportion of mineral nitrogen in different soil layers was $0.01-2.0 \%$ of the total nitrogen, and most of the mineral nitrogen was in the form of ammonium (Tables 2, 4). The amounts of nutrients were small in control samples taken from a forest outside the feedlot.

The mean content of $\mathrm{NH}_{4}-\mathrm{N}$ in the front parts of the pens was greater than in the back parts (Table 4). The difference was especially clear in the deep soil layers: $40-60$ and $60-100 \mathrm{~cm}$. At a depth of 40-60 cm, for example, the mean $\mathrm{NH}_{4}-\mathrm{N}$ content was $40-70 \mathrm{mg} \mathrm{l}^{-1}$ in the front parts and only 2-3 $\mathrm{mg} \mathrm{l}^{-1}$ in the back parts of pens. On the other hand there was a lot of variation in $\mathrm{NH}_{4}-\mathrm{N}$ contents. In control samples the maximum $\mathrm{NH}_{4}-\mathrm{N}$ content was $6.2 \mathrm{mg} \mathrm{l}^{-1}$ in the soil surface.

The $\mathrm{NO}_{3}-\mathrm{N}$ content in the soil was consistently smaller than the $\mathrm{NH}_{4}-\mathrm{N}$ content (Table 4). Some $\mathrm{NO}_{3}$-N was also found in deep soil layers in the feedlot. In the control samples small concentrations of $\mathrm{NO}_{3}-\mathrm{N}$, below $0.15 \mathrm{mg} \mathrm{l}^{-1}$, were measured. In autumn 1998 the amounts of $\mathrm{NO}_{3}-\mathrm{N}$ were low after a rainy summer.

After two winters or one winter of use, the mean amounts of $\mathrm{NH}_{4}-\mathrm{N}$ in a 1-meter deep soil layer were 470 and $350 \mathrm{~kg} \mathrm{ha}^{-1}$, respectively in the front parts of pens (Fig. 2a). After 4-5 winter seasons of use, the mean amounts of $\mathrm{NH}_{4}-\mathrm{N}$ in pens were 550 and $860 \mathrm{~kg} \mathrm{ha}^{-1}$ (Fig. 2e). The mean amounts of $\mathrm{NH}_{4}-\mathrm{N}$ in the back parts also increased from 40 to $50 \mathrm{~kg} \mathrm{ha}^{-1}$ in pens $1-2$ and from 80 to $150 \mathrm{~kg} \mathrm{ha}^{-1}$ in pens 3-4 from the experimental year of 1997 to the year 1999 (Figs. $2 \mathrm{a}, \mathrm{e})$. In the nearby forest the mean amount was only $7 \mathrm{~kg} \mathrm{ha}^{-1}$. In addition, the mean amount of $\mathrm{NO}_{3}-\mathrm{N}$ rose to $18 \mathrm{~kg} \mathrm{ha}^{-1}$ in the rear parts and 33 $\mathrm{kg} \mathrm{ha}^{-1}$ in the front areas of the pens (Fig. 2f). In 


\section{AGRICULTURAL AND FOOD SCIENCE IN FINLAND}

Vol. 11 (2002): 355-369.
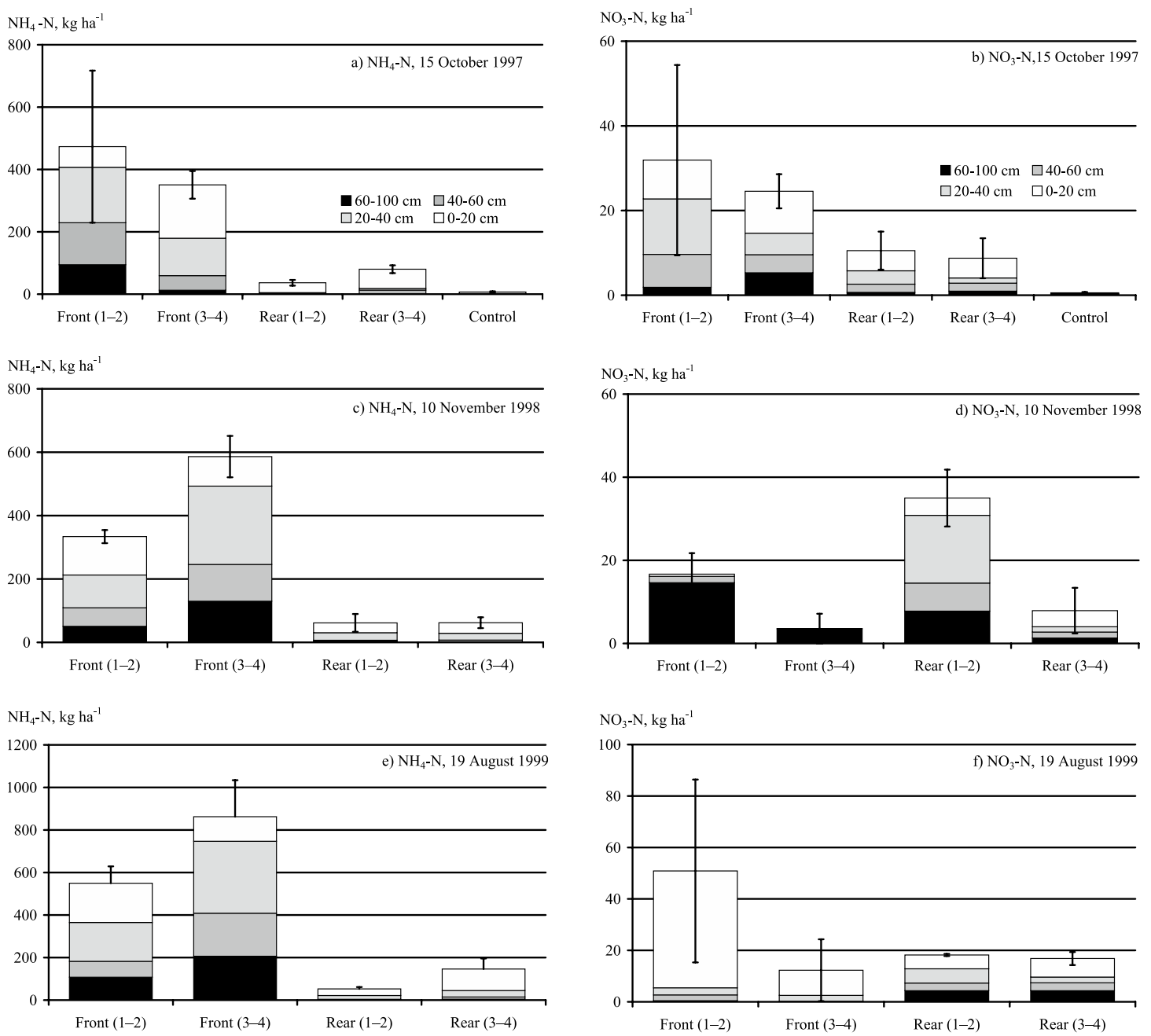

Fig. 2. Mean amounts of $\mathrm{NH}_{4}-\mathrm{N}$ and $\mathrm{NO}_{3}-\mathrm{N}\left(\mathrm{kg} \mathrm{ha}^{-1}\right)$ in different soil depths in front part of pens, back part of pens and outside the feedlot (= control) in 1997-1999. The error bar shows maximum and minimum value in the 1-m soil layer for 2 pens and 2 control.

the pen 2, small calves were raised only in the front part of the pens during last two experimental winters (Table 1), thus the amount of $\mathrm{NH}_{4}-\mathrm{N}$ did not increase in the rear part of the pen.

\section{Easily soluble $P$}

According to the Finnish fertility classification for soil (Viljavuuspalvelu 2001), the mean con- tent of $\mathrm{P}_{\mathrm{AAAc}}$ in topsoil $(0-20 \mathrm{~cm})$ was high (29 $\mathrm{mg}^{-1}$ ) especially in the front parts of the pens in 1999 (Table 5). In the back parts the mean $\mathrm{P}_{\mathrm{AAAc}}$ content of $6.0 \mathrm{mg} \mathrm{l}^{-1}$ corresponds to a fair phosphorus status for a cultivated soil. Deeper in the soil, the $\mathrm{P}_{\mathrm{AAAc}}$ content decreased rapidly. In control samples taken from the adjacent forest the $\mathrm{P}_{\text {AAAc }}$ content was less than $3 \mathrm{mg} \mathrm{l}^{-1}$, which indicates the natively low background level and initial soil $\mathrm{P}$ status. 
Uusi-Kämppä, J. N and P losses from a feedlot for suckler cows

Table 4. Mean concentrations (mean \pm S.D.) of $\mathrm{NH}_{4}-\mathrm{N}$ and $\mathrm{NO}_{3}-\mathrm{N}$ at different soil depths, 1997-1999.

\begin{tabular}{|c|c|c|c|c|c|c|}
\hline \multirow{3}{*}{$\begin{array}{l}\text { Date/ } \\
\text { Depth }(\mathrm{cm})\end{array}$} & \multicolumn{3}{|c|}{$\mathrm{NH}_{4}-\mathrm{N}, \mathrm{mg} \mathrm{l}^{-1}$} & \multicolumn{3}{|c|}{$\mathrm{NO}_{3}-\mathrm{N}, \mathrm{mg} \mathrm{l}^{-1}$} \\
\hline & \multicolumn{2}{|c|}{ Location in pens } & \multirow[b]{2}{*}{ Control $^{(\mathrm{b})}$} & \multicolumn{2}{|c|}{ Location in pens } & \multirow[b]{2}{*}{ Control $^{(b)}$} \\
\hline & Front ${ }^{(a)}$ & Rear (a) & & Front (a) & Rear $^{\text {(a) }}$ & \\
\hline \multicolumn{7}{|c|}{15 October 1997} \\
\hline $0-5$ & $73.2 \pm 73.9$ & $36.5 \pm 14.6$ & $4.2(2.2-6.2)$ & $3.0 \pm 2.4$ & $2.7 \pm 1.0$ & $0.06(0.06-0.06)$ \\
\hline $5-10$ & $59.6 \pm 43.6$ & $36.8 \pm 16.2$ & $2.9(1.6-4.2)$ & $3.1 \pm 2.46$ & $3.0 \pm 1.6$ & $0.09(0.05-0.12)$ \\
\hline $10-20$ & $52.3 \pm 29.1$ & $10.2 \pm 5.7$ & $1.4(1.0-1.7)$ & $6.4 \pm 5.6$ & $1.9 \pm 1.9$ & $0.10(0.05-0.15)$ \\
\hline $20-40$ & $74.4 \pm 30.4$ & $2.1 \pm 1.9$ & $0.4(0.4-0.5)$ & $4.6 \pm 5.2$ & $1.1 \pm 1.1$ & $0.07(0.05-0.09)$ \\
\hline $40-60$ & $45.4 \pm 41.6$ & $3.3 \pm 5.5$ & $0.2(0.2-0.3)$ & $3.0 \pm 1.9$ & $1.0 \pm 0.8$ & $0.04(0.04-0.05)$ \\
\hline $60-100$ & $13.4 \pm 16.5$ & $0.2 \pm 0.1$ & $0.2(0.1-0.2)$ & $0.9 \pm 0.8$ & $0.2 \pm 0.2$ & $0.04(0.02-0.06)$ \\
\hline \multicolumn{7}{|c|}{10 November 1998} \\
\hline $0-10$ & n.d. & $17.6 \pm 5.4$ & n.d. & n.d. & $2.5 \pm 2.4$ & n.d. \\
\hline $10-20$ & n.d. & $14.4 \pm 5.2$ & n.d. & n.d. & $1.6 \pm 1.3$ & n.d. \\
\hline $0-20$ & $53.6 \pm 8.7$ & n.d. & n.d. & $0.1 \pm 0.3$ & n.d. & n.d. \\
\hline $20-40$ & $87.7 \pm 52.5$ & $11.3 \pm 7.5$ & n.d. & $0.0 \pm 0.0$ & $4.4 \pm 5.8$ & n.d. \\
\hline $40-60$ & $43.7 \pm 19.5$ & $1.9 \pm 1.4$ & n.d. & $0.4 \pm 0.6$ & $2.0 \pm 1.5$ & n.d. \\
\hline $60-100$ & $22.6 \pm 13.0$ & $0.8 \pm 0.7$ & n.d. & $2.3 \pm 1.9$ & $1.1 \pm 1.2$ & n.d. \\
\hline \multicolumn{7}{|c|}{19 August 1999} \\
\hline $0-20$ & $65.8 \pm 13.9$ & $33.0 \pm 24.2$ & n.d. & $13.8 \pm 20.0$ & $3.1 \pm 1.3$ & n.d. \\
\hline $20-40$ & $130.2 \pm 67.3$ & $11.9 \pm 7.3$ & n.d. & $1.3 \pm 1.4$ & $2.0 \pm 1.0$ & n.d. \\
\hline $40-60$ & $69.2 \pm 47.0$ & $3.3 \pm 3.1$ & n.d. & $0.6 \pm 1.1$ & $1.5 \pm 0.7$ & n.d. \\
\hline $60-100$ & $39.3 \pm 16.4$ & $0.7 \pm 0.7$ & n.d. & $0.1 \pm 0.1$ & $1.1 \pm 0.4$ & n.d. \\
\hline
\end{tabular}

n.d. $=$ Not determined

(a) $=$ Contains four replicates.

(b) $=$ Values in parentheses indicate the range between two replicates.

S.D. = Standard deviation.

\section{Percolation water}

The concentrations of $\mathrm{NH}_{4}-\mathrm{N}, \mathrm{TN}$ and TP in percolation water were the highest in the front parts of the pens, whereas the concentrations of $\mathrm{PO}_{4}^{-}$ $\mathrm{P}$ and $\mathrm{NO}_{3}$ were the highest in the back parts (Table 6). On the other hand, most samples in the front parts were taken from pens 1, 3 and 4, and in back part from the pen 3 , because the other lysimeters did not work properly. The concentration of TN was always high in the front part of the pen 3 (496-1600 $\mathrm{mg}^{-1}$ ). In the front parts of pens 4 and 1 , the concentrations of TN were 164-758 and 44.0-2080 $\mathrm{mg}^{-1}$, respectively.

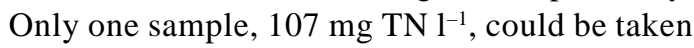
from the front part of pen 2 . In all samples most of nitrogen was in the form of $\mathrm{NH}_{4}-\mathrm{N}$. In the front part of the feedlot the mean concentration of $\mathrm{NO}_{3}$ - $\mathrm{N}$ was $0.01-0.20 \mathrm{mg} \mathrm{l}^{-1}$, but in the back part it was 3.1-29.2 $\mathrm{mg} \mathrm{l}^{-1}$ (Table 6). In the control lysimeters the nitrogen concentrations and volumes of percolation water were small.

The highest mean concentration of TP (1.7$28.2 \mathrm{mg} \mathrm{l}^{-1}$ ) was found in the percolation water collected in the front part of the feedlot (Table 6). The concentration of $\mathrm{PO}_{4}-\mathrm{P}$ was at first higher at the rear $\left(0.10-0.77 \mathrm{mg} \mathrm{l}^{-1}\right)$ as compared to that measured by lysimeters at the front (0.01-0.07 $\left.\mathrm{mg}^{-1}\right)$, but it also rose to a very high value of $7.02 \mathrm{mg} \mathrm{l}^{-1}$ in front part in 2000. The concentrations of $\mathrm{PO}_{4}-\mathrm{P}, \mathrm{TP}, \mathrm{NH}_{4}-\mathrm{N}$ and $\mathrm{TN}$ were also extremely high in the percolation water under 
Vol. 11 (2002): 355-369.

Table 5. Mean concentration of easily soluble $\mathrm{P}\left(\mathrm{P}_{\text {AAAc }}\right)$ at different soil depths, 1997-1999. Values in parentheses indicate the range between two replicates.

\begin{tabular}{|c|c|c|c|c|c|c|c|c|}
\hline \multirow[b]{4}{*}{ Date/Depth $(\mathrm{cm})$} & \multicolumn{7}{|c|}{$\mathrm{P}_{\mathrm{AAAc}}, \mathrm{mg} \mathrm{l}^{-1}$} & \multirow{4}{*}{ Control } \\
\hline & & & & Location & in pens & & & \\
\hline & \multicolumn{4}{|c|}{ Front } & \multicolumn{3}{|c|}{ Rear } & \\
\hline & Pens & 1 and 2 & Pen & s 3 and 4 & Pens & 1 and 2 & Pens 3 and 4 & \\
\hline \multicolumn{9}{|l|}{15 October 1997} \\
\hline $0-5$ & 17.8 & $(7.3-28.2)$ & 10.8 & $(8.4-13.2)$ & 11.3 & $(7.9-14.6)$ & $19.9(16.3-23.5)$ & $3.0 \quad(2.9-3.1)$ \\
\hline $5-10$ & 12.9 & $(3.5-22.3)$ & 8.6 & $(6.6-10.5)$ & 2.9 & $(2.3-3.4)$ & $9.5 \quad(8.9-10.0)$ & $1.9(1.2-2.5)$ \\
\hline $10-20$ & 8.1 & $(2.5-13.6)$ & 6.0 & $(5.9-6.0)$ & 0.7 & $(0.7-0.7)$ & $1.6(0.8-2.4)$ & $0.9 \quad(0.6-1.1)$ \\
\hline $20-40$ & 1.8 & $(1.0-2.6)$ & 1.6 & $(1.0-2.2)$ & 0.6 & $(0.5-0.6)$ & $0.7 \quad(0.7-0.7)$ & $0.7 \quad(0.5-0.9)$ \\
\hline $40-60$ & 0.7 & $(0.5-0.8)$ & 0.7 & $(0.4-0.9)$ & 1.0 & $(0.6-1.4)$ & $1.0(0.7-1.2)$ & $1.5(0.6-2.3)$ \\
\hline $60-100$ & 0.6 & $(0.3-0.9)$ & 0.6 & $(0.4-0.7)$ & 1.4 & $(0.9-1.8)$ & $1.4(1.0-1.7)$ & $1.8 \quad(0.9-2.6)$ \\
\hline \multicolumn{9}{|l|}{10 November 1998} \\
\hline $0-10$ & - & & - & & 9.7 & $(5.7-13.6)$ & $8.7 \quad(3.9-13.6)$ & \\
\hline $10-20$ & - & & - & & 1.1 & $(0.9-1.3)$ & $0.8 \quad(0.7-0.9)$ & \\
\hline 0-20 & 10.5 & $(7.8-13.1)$ & 19.9 & $(12.8-27.0)$ & - & & - & \\
\hline $20-40$ & 1.3 & $(1.3-1.4)$ & 4.0 & $(3.7-4.3)$ & 0.7 & $(0.6-0.7)$ & $2.1 \quad(0.9-3.2)$ & \\
\hline $40-60$ & 0.9 & $(0.6-1.2)$ & 1.1 & $(1.1-1.1)$ & 1.0 & $(0.7-1.3)$ & $1.0(0.8-1.2)$ & \\
\hline $60-100$ & 1.0 & $(0.8-1.2)$ & 0.8 & $(0.7-0.9)$ & 1.4 & $(1.1-1.7)$ & $1.5(1.2-1.7)$ & \\
\hline \multicolumn{9}{|l|}{19 August 1999} \\
\hline $0-20$ & 41.1 & $(5.7-76.5)$ & 17.1 & $(11.8-22.4)$ & 5.3 & $(3.8-6.8)$ & $6.8(3.4-10.3)$ & \\
\hline $20-40$ & 2.1 & $(2.0-2.2)$ & 13.2 & $(9.3-17.1)$ & 1.0 & $(1.0-1.1)$ & 1.4 (1.4-1.4) & \\
\hline $40-60$ & 1.4 & $(1.2-1.5)$ & 4.0 & $(3.7-4.3)$ & 1.3 & $(1.0-1.6)$ & $1.9(1.6-2.3)$ & \\
\hline $60-100$ & 1.6 & $(1.6-1.7)$ & 1.5 & $(1.4-1.6)$ & 2.5 & $(2.2-2.7)$ & $3.1 \quad(1.7-4.5)$ & \\
\hline
\end{tabular}

- = No sample available

the bedded areas (Table 7). No percolation water was collected by the lysimeters situated in the 3-walled shed in pens 1 and 2 . The mean annual loads of $\mathrm{PO}_{4}-\mathrm{P}, \mathrm{TP}, \mathrm{NO}_{3}-\mathrm{N}, \mathrm{NH}_{4}-\mathrm{N}$, and $\mathrm{TN}$ via percolation water in pens 1,3 and 4 were estimated to be 2, 13, 0.1, 660 and $820 \mathrm{~kg} \mathrm{ha}^{-1}$ respectively from a front part of the open feedlot. The estimated annual loads of $\mathrm{PO}_{4}-\mathrm{P}, \mathrm{TP}$, $\mathrm{NO}_{3}-\mathrm{N}, \mathrm{NH}_{4}-\mathrm{N}$ and $\mathrm{TN}$ were $0.2,0.5,8,16$ and $30 \mathrm{~kg} \mathrm{ha}^{-1}$ in the back part of the feedlot. The result from pen 2 was skipped because only one sample was obtained from the front lysimeter. In the control lysimeters the annual estimates of $\mathrm{PO}_{4}-\mathrm{P}$ and TP were under $0.1 \mathrm{~kg} \mathrm{ha}^{-1}$, but the figures for $\mathrm{NH}_{4}-\mathrm{N}, \mathrm{NO}_{3}-\mathrm{N}$ and $\mathrm{TN}$ were $0.4,0.4$ and $1.6 \mathrm{~kg} \mathrm{ha}^{-1}$.

\section{Ditch water}

The concentrations of TP, TN and $\mathrm{NH}_{4}-\mathrm{N}$ were especially high in spring and decreased in summer (Fig. 3). The concentration of $\mathrm{PO}_{4}-\mathrm{P}$ in the ditch water was at the same level as that in the percolation water collected from the back part of the feedlot. The total amounts of $\mathrm{PO}_{4}-\mathrm{P}, \mathrm{TP}$, $\mathrm{NH}_{4}-\mathrm{N}, \mathrm{NO}_{3}-\mathrm{N}$ and $\mathrm{TN}$ were $0.03,0.6,4.6,0.07$ and $7 \mathrm{~kg}$ respectively from the lot area during the experimental period of 25 April-27 August 1998. These quantities correspond to $0.07 \mathrm{~kg}$ $\mathrm{PO}_{4}-\mathrm{P} \mathrm{ha}^{-1}, 1.4 \mathrm{~kg} \mathrm{TP} \mathrm{ha}^{-1}$ and $16 \mathrm{~kg} \mathrm{TN} \mathrm{ha}^{-1}$ by far exceeding the rates leached from average cultivated land. 


\section{Uusi-Kämppä, J. N and P losses from a feedlot for suckler cows}

Table 6. Percolation water amount, and flow-weighted mean $\mathrm{PO}_{4}-\mathrm{P}$, total $\mathrm{P}(\mathrm{TP}), \mathrm{NH}_{4}-\mathrm{N}, \mathrm{NO}_{3}-\mathrm{N}$ and total $\mathrm{N}$ (TN) concentrations in percolation water in the front and rear of pens and the control area outside the feedlot.

\begin{tabular}{|c|c|c|c|c|c|c|c|c|c|}
\hline \multirow[b]{2}{*}{ Date } & \multicolumn{3}{|c|}{ Percolation water, $\mathrm{mm}$} & \multicolumn{3}{|c|}{$\mathrm{PO}_{4}-\mathrm{P}, \mathrm{mg} \mathrm{l}^{-1}$} & \multicolumn{3}{|c|}{$\mathrm{TP}, \mathrm{mg} \mathrm{l}^{-1}$} \\
\hline & Front & Rear & Control & Front & Rear & Control & Front & Rear & Control \\
\hline 27 May 1998 & 195 & 124 & 7 & 0.07 & 0.10 & 0.01 & 3.9 & 0.44 & 0.04 \\
\hline 17 Jun 1998 & 81 & 108 & 68 & 0.02 & 0.28 & 0.02 & 2.9 & 0.68 & 0.05 \\
\hline 18 Aug 1998 & 116 & 50 & 3 & 0.03 & 0.22 & 0.13 & 2.3 & 0.39 & 0.08 \\
\hline 21 Sep 1998 & 75 & 56 & 2 & 0.02 & 0.77 & 0.05 & 1.7 & 1.43 & 0.13 \\
\hline 28 Oct 1998 & 56 & - & 4 & 0.01 & - & 0.08 & 3.3 & - & 0.41 \\
\hline 19 Jul 1999 & 103 & 46 & 63 & 0.41 & 0.19 & 0.03 & 12.6 & 0.41 & 0.07 \\
\hline 07 Jun 2000 & 123 & 53 & 4 & 7.02 & 0.21 & 0.03 & 21.4 & 0.40 & 0.06 \\
\hline 19 Jul 2000 & 88 & 23 & 33 & 6.30 & 0.43 & 0.15 & 28.2 & 0.62 & 0.24 \\
\hline
\end{tabular}

\begin{tabular}{|c|c|c|c|c|c|c|c|c|c|}
\hline \multirow[b]{2}{*}{ Date } & \multicolumn{3}{|c|}{$\mathrm{NH}_{4}-\mathrm{N}, \mathrm{mg} \mathrm{l}^{-1}$} & \multicolumn{3}{|c|}{$\mathrm{NO}_{3}-\mathrm{N}, \mathrm{mg} \mathrm{l}^{-1}$} & \multicolumn{3}{|c|}{$\mathrm{TN}, \mathrm{mg} \mathrm{l}^{-1}$} \\
\hline & Front & Rear & Control & Front & Rear & Control & Front & Rear & Control \\
\hline 27 May 1998 & 491 & 10.6 & 0.6 & 0.09 & 3.4 & 0.99 & 557 & 16.0 & 3.5 \\
\hline 17 Jun 1998 & 292 & 24.9 & 0.3 & 0.06 & 3.1 & 0.20 & 337 & 34.8 & 2.0 \\
\hline 18 Aug 1998 & 241 & 39.5 & 1.9 & 0.03 & 16.6 & 0.88 & 253 & 57.6 & 11.7 \\
\hline 21 Sep 1998 & 198 & 18.9 & 4.7 & 0.08 & 13.1 & 7.74 & 246 & 61.5 & 15.7 \\
\hline 28 Oct 1998 & 123 & - & 2.7 & 0.01 & - & 5.43 & 206 & - & 13.9 \\
\hline 19 Jul 1999 & 1121 & 6.8 & 1.0 & 0.10 & 21.9 & 1.37 & 1369 & 31.8 & 4.3 \\
\hline 07 Jun 2000 & 642 & 32.0 & 0.7 & 0.20 & 29.1 & 0.04 & 868 & 67.4 & 1.4 \\
\hline 19 Jul 2000 & 397 & 32.2 & 0.7 & 0.15 & 29.2 & 0.05 & 554 & 72.6 & 2.5 \\
\hline
\end{tabular}

$-=$ No sample available

Table 7. Flow-weighted mean $\mathrm{PO}_{4}-\mathrm{P}$, total $\mathrm{P}(\mathrm{TP}), \mathrm{NH}_{4}-\mathrm{N}, \mathrm{NO}_{3}-\mathrm{N}$ and total $\mathrm{N}(\mathrm{TN})$ concentrations in percolation water, and percolation water amount in the bedded areas in pens 3-4.

\begin{tabular}{lrccccc}
\hline Date & $\mathrm{PO}_{4}-\mathrm{P}$ & $\mathrm{TP}$ & $\mathrm{NH}_{4}-\mathrm{N}$ & $\mathrm{NO}_{3}-\mathrm{N}$ & $\mathrm{TN}$ & \multicolumn{2}{c}{$\begin{array}{c}\text { Percolation water } \\
\mathrm{mm}\end{array}$} \\
\cline { 2 - 5 } & & & $\mathrm{mg} \mathrm{l}^{-1}$ & & & 53 \\
\hline 28 Oct 1998 & 6.4 & 38.5 & 94.6 & 0.3 & 161 & 26 \\
19 Jul 1999 & 17.8 & 45.1 & 93.1 & 1.3 & 215 & 26 \\
\hline
\end{tabular}

\section{Discussion}

Pens 1 and 2 were established in 1995, and pens 3 and 4 in 1996. Thus the first results from the feedlot in autumn 1997 explain the situation after the feedlot had been used for 1-2 years. When the experiment was coming to an end in spring 2000 , the pens had been in use for $4-5$ years.
The control samples taken from the adjacent forest represent the situation before the use of feedlots. The levels of $\mathrm{NH}_{4}-\mathrm{N}, \mathrm{NO}_{3}-\mathrm{N}$ and $\mathrm{P}_{\text {AAAc }}$ were already very high in 1997, when the pens had been in use for 1 or 2 years. The nutrients concentrated very quickly in the soil of the pens. In autumn 1999, the $\mathrm{NH}_{4}-\mathrm{N}$ and $\mathrm{P}_{\mathrm{AAAc}}$ levels were higher in the deep soil than they had been in autumn 1997. The accumulation of nutrients oc- 
Vol. 11 (2002): 355-369.

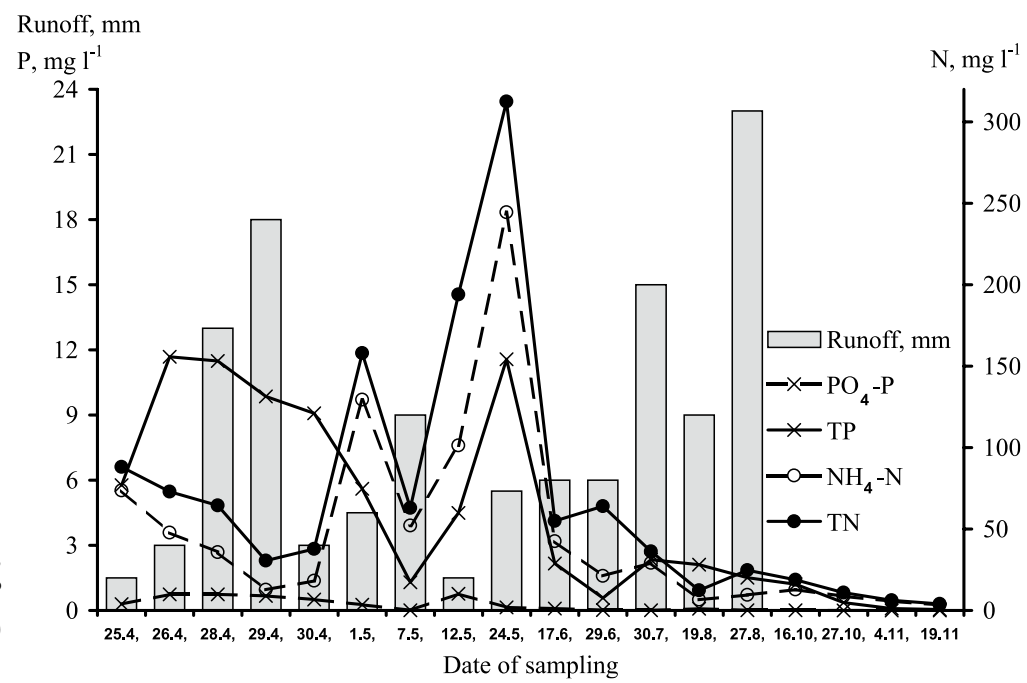

Fig. 3. Concentrations of $\mathrm{NO}_{3}-\mathrm{N}$, $\mathrm{NH}_{4}-\mathrm{N}$, total nitrogen (TN), $\mathrm{PO}_{4}-\mathrm{P}$ and total phosphorus (TP) $\left(\mathrm{mg} \mathrm{l}^{-1}\right)$ in the ditch water in 1998.

Date of sampling

curred in spite of the fact that the surface soil with dung was removed from the front part of the feedlot every autumn during the experiment to avoid environmental loading. In control samples the nutrient contents were small.

Suckler cows were fed on the feedlot for 8 months annually. If it is calculated that a suckler cow excretes $55 \mathrm{~kg}$ of $\mathrm{N}$ and $9 \mathrm{~kg}$ of $\mathrm{P}$ in dung and urine annually (Ministry of the Environment 1998), then an 8-month loading of $\mathrm{N}$ and $P$ from 8 cows in a pen amounts to

$8 \times(8 / 12) \times 55 \mathrm{~kg} \mathrm{~N} \mathrm{yr}^{-1}=290 \mathrm{~kg} \mathrm{~N} \mathrm{yr}^{-1}$ and $8 \times(8 / 12) \times 9 \mathrm{~kg} \mathrm{P} \mathrm{yr}^{-1}=48 \mathrm{~kg} \mathrm{P} \mathrm{yr}^{-1}$.

In autumn 1997, only $22 \mathrm{~kg}$ of mineral nitrogen was found in the soil of each of pens 3 and 4 after one winter, and $33 \mathrm{~kg}$ in each of pens 1 and 2 after two winter seasons of cattle raising. It was estimated that in the case of each pen about $40 \mathrm{~kg}$ (mean of the front and rear parts of the pens) of TN was lost annually via percolation water, and only $2 \mathrm{~kg}$ TN via ditch water. Since only $22-26 \%$ of $\mathrm{N}$ per pen was found in the soil and the percolation and ditch water, a significant proportion of the nitrogen may have been lost via ammonia volatilisation and somewhat less by way of nitrous oxide emissions. Nitrogen leaching may also have been greater than estimated because lysimeters did not work well. Maybe the particle size of quartz sand was too small and the funnel was easily blocked by organic material, or tubes were destroyed by the cows despite the fact that the lysimeter bottles and funnels were protected from cloven hoofs by a metal grating. Some of the nitrogen was also removed with the surface soil during cleaning of the front parts of the pens every autumn. In Sweden, cleaning of a porous outdoor area for pigs was found to reduce the annual load of mineral nitrogen from $1000-2000 \mathrm{~kg} \mathrm{ha}^{-1}$ to c. 20 $\mathrm{kg} \mathrm{ha}^{-1}$ (von Wachenfelt 2001).

About $0.7 \mathrm{~kg}$ of TP in percolation water was lost annually from each pen. The mean annual load of TP (about $7 \mathrm{~kg} \mathrm{ha}^{-1}$ ) leached from the front (13 $\left.\mathrm{kg} \mathrm{TP} \mathrm{ha}^{-1}\right)$ and rear $\left(0.5 \mathrm{~kg} \mathrm{TP} \mathrm{ha}{ }^{-1}\right)$ was about five times that of cropped fields. Although the concentration of TP was sometimes high (flow-weighted mean $5.2 \mathrm{mg}^{-1}$, range $\left.0.04-11.7 \mathrm{mg}^{-1}\right)$ in the ditch water, the load of TP was small ( $0.6 \mathrm{~kg}$ per feedlot) because of the small water volume $\left(118 \mathrm{~m}^{3}\right)$, which indicated a runoff of $27 \mathrm{~mm}$ from the feedlot (Fig. 3).

Concentrations of $\mathrm{NH}_{4}-\mathrm{N}, \mathrm{TN}$ and $\mathrm{TP}$ were high in percolation and ditch water. Both $\mathrm{NH}_{4}-\mathrm{N}$ concentrations in percolation water and $\mathrm{NH}_{4}-\mathrm{N}$ levels in soil were high in the front part of the feedlot, where the suckler cows spent most of 


\section{Uusi-Kämppä, J. N and P losses from a feedlot for suckler cows}

their time. In this area, the concentrations of $\mathrm{NH}_{4}-\mathrm{N}$ and $\mathrm{TN}$ in percolation water were as high as those which Yang and Lorimor (2000) reported in surface runoff from an American concrete feedlot (380 beef animals per $2.3 \mathrm{ha}$ ): $108 \mathrm{mg}$ $\mathrm{NH}_{4}-\mathrm{N}^{-1}$ and $177 \mathrm{mg} \mathrm{TN}{ }^{-1}$. In Canada, Kennedy et al. (1999) presented the mean concentrations of $\mathrm{TN}, \mathrm{NH}_{4}-\mathrm{N}$ and $\mathrm{TP}$ at three old sites. The figures varied annually within the ranges of 211-305, 51.7-95.3 and 43.5-75.3 mg $1^{-1}$ respectively at a feedlot (43 ha) for $12,000-$ 25,000 head of cattle. At a new site the concentrations were lower: $25.5 \mathrm{mg} \mathrm{TN}{ }^{-1}, 4.7 \mathrm{mg}$ $\mathrm{NH}_{4}-\mathrm{N}^{-1}$ and $6.8 \mathrm{mg} \mathrm{TP}^{-1}$. At Tohmajärvi, concentrations of TP $\left(1.73-28.21 \mathrm{mg}^{-1}\right)$ in the front part of the feedlot were lower than concentrations reported in American studies: $34 \mathrm{mg} \mathrm{l}^{-1}$ (Yang and Lorimor 2000); and 43.5-73.5 $\mathrm{mg} \mathrm{l}^{-1}$ (Kennedy et al. 1999). Obviously some of the TP was bound in the soil of the pens at Tohmajärvi.

Both the level of $\mathrm{NO}_{3}-\mathrm{N}$ in soil and the concentration of $\mathrm{NO}_{3}-\mathrm{N}$ in percolation water increased in the back parts of the pens during the experiment. The concentration of $\mathrm{NO}_{3}-\mathrm{N}(3-29$ $\mathrm{mg}^{-1}$ ) was as high as Williams et al. (2000) reported for the pig farming systems $\left(8-28 \mathrm{mg} \mathrm{l}^{-1}\right)$ in the UK in the first winter. In the British study, the concentration of $\mathrm{NO}_{3}-\mathrm{N}$ rose to $105-111 \mathrm{mg}$ $1^{-1}$ in the second winter. Due to the low $\mathrm{pH}$ (3.75.6) in the peat soil, little nitrification of manure $\mathrm{NH}_{4}-\mathrm{N}$ probably occurred in the present soils, and the concentration of $\mathrm{NO}_{3}-\mathrm{N}$ did not increase to values as high as in those contained in the study of Williams et al. (2000). However, the highest $\mathrm{NO}_{3}-\mathrm{N}$ concentrations in the feedlot were twice or even three times as much as that set by the EU as the limit for drinking water.

The $\mathrm{PO}_{4}-\mathrm{P}$ concentrations measured in percolation and ditch waters in the feedlot were usually as high as those measured in the runoff waters from Finnish cropped fields - 0.03$0.6 \mathrm{mg} \mathrm{l}^{-1}$ (e.g. Puustinen 1994, Turtola and YliHalla 1999, Jansson et al. 2000) - or peat-cutting areas - 0.003-0.670 $\mathrm{mg}^{-1}$ (Kløve 2001). In 2000 , the concentration of $\mathrm{PO}_{4}^{-} \mathrm{P}$ in percolation water rose to $6.3-7.0 \mathrm{mg}^{-1}$, which was a figure 10-30 times greater than for runoff water from cropped fields. The concentrations of TP, $\mathrm{NH}_{4}-\mathrm{N}$, TN and sometimes also $\mathrm{NO}_{3}-\mathrm{N}$ in feedlot waters were as much as 10-20-, 2000-3000-, 30-60- and 2-4 times higher than levels expected in runoff waters from Finnish clay fields (e.g. Puustinen 1994, Turtola and Paajanen 1995, Uusi-Kämppä and Yläranta 1996). In Finnish forested basins, the mean concentrations of $\mathrm{NH}_{4}$ $\mathrm{N}, \mathrm{NO}_{3}-\mathrm{N}, \mathrm{TN}, \mathrm{PO}_{4}-\mathrm{P}$ and TP were $0.007-0.100$, $0.049-1.200,0.560-1.700,0.017-0.045$ and 0.022-0.060 $\mathrm{mg} \mathrm{l}^{-1}$ respectively in 1981-1992 (Rekolainen 1989, Pietiläinen and Rekolainen 1991, Joensuu et al. 2001). The nutrient loading from the open feedlot was many times greater than that from virgin forests.

The concentrations of $\mathrm{NH}_{4}-\mathrm{N}$ and $\mathrm{TN}$ in control lysimeters, that of $\mathrm{NO}_{3}-\mathrm{N}$ in the control area and in the front parts of the pens, and that of TP in the control area and in the back parts of the pens were the same as Kløve (2001) had measured in the waters of peat-cutting areas. But in the other parts of the pens, the mean maximum concentration, as compared to waters in peatcutting areas, was as much as 10-50-fold in the case of TP, 100-fold in that of $\mathrm{NH}_{4}-\mathrm{N}$ and TN, and 10 -fold in that of $\mathrm{NO}_{3}-\mathrm{N}$. Significantly high phosphorus leaching from peat soil indicates the low capacity of peat soil to bind phosphorus. The surface application of slurry on grass fields has been found to increase the phosphorus level in the soil surface within a few years and to augment the phosphorus export to surface water via surface runoff from the grass (Turtola and YliHalla 1999, Sauer et al. 2000). In feedlots and exercise yards the increase of $\mathrm{P}_{\mathrm{AAAc}}$ in the top layer of soil may also increase phosphorus loading in surface runoff.

Water-soluble nutrients were mainly able to leach directly to the ground water from the feedlot at Tohmajärvi, because the soil was rather coarse. However, in this coarse soil with an organic top layer, compaction of the surface soil also resulted in increased surface runoff in the front part of the feedlot, especially in autumn 1998. The fact that $\mathrm{NH}_{4}-\mathrm{N}$, rather than $\mathrm{NO}_{3}-\mathrm{N}$, is such a dominant form of mineral $\mathrm{N}$ suggests 
Vol. 11 (2002): 355-369.

that nitrification was probably inhibited in this soil. This phenomenon is probably attributable to low $\mathrm{pH}$ of the soil. This occurrence of $\mathrm{N}$ as $\mathrm{NH}_{4}-\mathrm{N}$ may also to some extent retard $\mathrm{N}$ leaching from soil. Even thought the amount of $\mathrm{NH}_{4}-\mathrm{N}$ was substantially elevated in the soil, the exchange sites were not saturated with $\mathrm{NH}_{4}-\mathrm{N}$. In this experiment, there was $0.04-1.13 \mathrm{cmol}$ $\mathrm{NH}_{4}-\mathrm{N} \mathrm{kg}^{-1}$ soil, while the usual cation exchange capacity in soils of this kind is 10-25 cmol(+) $\mathrm{kg}^{-1}$ (Marttila 1965).

\section{Conclusions}

According this study, raising cattle on feedlots or allowing them access to exercise yards is likely to increase nutrient losses into adjacent wells and ground and surface waters in areas where large numbers of animals are kept outdoors. The risk is greatest on large farms where many animals are kept on feedlots all year round. How- ever, dairy cows are not normally fed at exercise yards, and they spend only a few hours per week outdoors in winter. Therefore the nutrient amounts on the surface of exercise yards may not be as high as those presented in this study.

In northern regions, snow melt in spring is a risk if manure is not collected and removed from an exercise yard or feedlot before the thaw. The cleaning of yards is also important in summer in order to minimise nutrient runoff during periods of rain. On conventional dairy farms the risk may increase in future if numbers of dairy cows are penned and if the yards are not well planned, built and managed. More research is needed to investigate how runoff waters from feedlots and exercise yards can be cleaned on a farm.

Acknowledgements. I am especially grateful to Mrs. M. Manninen, M.Sc., for providing the experimental area. I also thank the staff of the Suckler Cow Unit for taking care for the pens and sampling, Ms. K. Grék for data processing, and Mr. Rod Fletcher for revising the English. This study was supported by funding from the Ministry of Agriculture and Forestry.

\section{References}

Carey, P.L., Rate, A.W. \& Cameron, K.C. 1997. Fate of nitrogen in pig slurry applied to a New Zealand pasture soil. Australian Journal of Soil Research 35: 941959.

Derome, J., Niska, K., Lindroos, A.-J. \& Välikangas, P. 1991. Ion-balance monitoring plots and bulk deposition in Lapland during July 1989-June 1990. In: Tikkanen, E. \& Varmola, M. (eds.). Research into forest damage connected with air pollution in Finnish Lapland and the Kola peninsula of the U.S.S.R.: A seminar held in Kuusamo, Finland, 25-26 May 1990. Metsäntutkimuslaitoksen tiedonantoja 373: 49-76.

EC 1804/1999. Council regulation (EC) No 1804/1999 of July 1999 supplementing Regulation (EEC) No 2092/ 91 on organic production of agricultural products and indications referring there to on agricultural products and foodstuffs to include livestock production.

Esala, M. 1991. Split application of nitrogen: effects on the protein in spring wheat and fate of ${ }^{15} \mathrm{~N}$-labelled nitrogen in the soil-plant system. Annales Agriculturae Fenniae 30: 219-309. (Diss.)
FAO 1998. World Reference Base for Soil Resources. World Soil Resources Reports 84. FAO, Rome. 88 p. Heinonen-Tanski, H. \& Uusi-Kämppä, J. 2001. Runoff of faecal micro-organisms and nutrients from perennial grass ley after application of slurry and mineral fertiliser. Water Science and Technology 43(12): 143146.

Jansson, H., Mäntylahti, V., Närvänen, A. \& Uusitalo, R. 2000. Phosphorus content of ditch sediment as indicator of critical source areas. Agricultural and Food Science in Finland 9: 217-221.

Joensuu, S., Ahti, E. \& Vuollekoski, M. 2001. Discharge water quality from old ditch networks in Finnish peatland forests. Mires and peat 52: 1-15.

Kennedy, B., Coleman, R.N., Gillund, G.M., Kotelko, B., Kotelko, M., MacAlpine, N. \& Penney, P. 1999. Feedlot runoff: Volume 1: Quantity and quality of rainfall and snowmelt runoff from pens. CAESA Research Project RES-109-94. CAESA Canada - Alberta Environmentally Sustainable Agriculture Agreement. $180 \mathrm{p}$. 
Uusi-Kämppä, J. N and P losses from a feedlot for suckler cows

Kløve, B. 2001. Characteristics of nitrogen and phosphorus loads in peat mining wastewater. Water Research 35: 2353-2362.

Manninen, M. 1999. Suckler cow beef production in marginal areas. In: International suckler cow workers' meeting, 13-16 September 1999, Greenmount College, Antrim, Northern Ireland. 4 p.

Marttila, U. 1965. Exchangeable cations in Finnish Soils. The Journal of the Scientific Agricultural Society of Finland 37: 148-161.

Ministry of Agriculture and Forestry 1999. MMM-RMOC4. Environmental control of livestock buildings. Decrees and directions for building issued by the Ministry of Agriculture and Forestry. In Finnish.

Ministry of the Environment 1998. Instructions for environmental protection in animal husbandry 30.9.1998. In Finnish. 27 p.

Misselbrook, T.H., Pain, B.F., Stone, A.C. \& Scholefield, D. 1995 Nutrient run-off following application of livestock wastes to grassland. Environmental Pollution 88: $51-56$.

Murphy, J. \& Riley, J.P. 1962. A modified single solution method for the determination of phosphate in natural waters. Analytica Chimica Acta 27: 31-36.

Paul, J.W. \& Zebarth, B.J. 1997. Denitrification and nitrate leaching during the fall and winter following dairy cattle slurry application. Canadian Journal of Soil Science 77: 231-240.

Pietiläinen, O.-P. \& Rekolainen, S. 1991. Dissolved reactive and total phosphorus load from agricultural and forested basins to surface waters in Finland. Aqua Fennica 21: 127-136.

Puustinen, M. 1994. Effect of soil tillage on erosion and nutrient transport in plough layer runoff. Publications of the Water Research Institute 17: 71-90. National Board of Waters and the Environment, Finland.

Rekolainen, S. 1989. Phosphorus and nitrogen load from forest and agricultural areas in Finland. Aqua Fennica 19: 95-107.

Sauer, T.J., Daniel, T.C., Nichols, D.J., West, C.P., Moore, P.A. Jr. \& Wheeler, G.L. 2000. Runoff water quality from poultry litter-treated pasture and forest sites. Journal of Environmental Quality 29: 515-521.

SFS 3025. Determination of phosphate in water. Finnish Standards Association SFS. Helsinki 1986. In Finnish. $10 \mathrm{p}$.

SFS 3026. Determination of total phosphorus in water. Digestion with peroxodisulphate. Finnish Standards Association SFS. Helsinki 1986. In Finnish. 11 p.

SFS 3030 . Determination of the sum of nitrite and nitrate nitrogen in water. Finnish Standards Association SFS. Helsinki 1990. In Finnish. 5 p.

SFS 3031. Determination of nitrogen in water. Oxidation with peroxodisulphate. Finnish Standards Association SFS. Helsinki 1990. In Finnish. 6 p.
SFS 3032. Determination of ammonia-nitrogen of water. Finnish Standards Association SFS. Helsinki 1976. In Finnish. 6 p.

Soil Survey Staff 1998. Keys to Soil Taxonomy. United States Department of Agriculture. Natural Resources Conservation Service. $8^{\text {th }}$ edition. 326 p.

Tares, T. \& Sippola, J. 1978. Changes in $\mathrm{pH}$, in electrical conductivity and in the extractable amounts of mineral elements in soil, and the utilization and losses of the elements in some field experiments. Acta Agriculturae Scandinavica, Supplementum 20: 90-113.

Turtola, E. \& Kemppainen, E. 1998. Nitrogen and phosphorus losses in surface runoff and drainage water after application of slurry and mineral fertilizer to perennial grass ley. Agricultural and Food Science in Finland 7: 569-581.

Turtola, E. \& Paajanen, A.1995. Influence of improved subsurface drainage on phosphorus losses and nitrogen leaching from a heavy clay soil. Agricultural Water Management 28: 295-310.

Turtola, E. \& Yli-Halla, M. 1999. Fate of phosphorus applied in slurry and mineral fertilizer: accumulation in soil and release into surface runoff water. Nutrient Cycling in Agroecosystems 55: 165-174.

Uusi-Kämppä, J. \& Yläranta, T. 1996. Effect of buffer strips on controlling soil erosion and nutrient losses in Southern Finland. In: Mulamoottil, G. et al. (eds.). Wetlands: Environmental Gradients, Boundaries, and Buffers. Boca Raton: CRC Press/Lewis Publishers. p. 221-235.

Viljavuuspalvelu 2000. Viljavuustutkimuksen tulkinta peltoviljelyssä. $31 \mathrm{p}$.

von Wachenfelt, H. 2001. The environmental load from outdoor areas and yards for pigs. In: Rom, H.B. \& Sorensen, C.G. (eds.). Sustainable handling and utilisation of livestock manure from animals to plants. Proceedings, NJF-Seminar no. 320, Denmark 16-19 January 2001. DIAS report 21: 24-33.

Vuorinen, J. \& Mäkitie, O. 1955. The method of soil testing in use in Finland. Agrogeological Publications 63: $1-44$.

Williams, J.R., Chambers, B.J., Hartley, A.R., Ellis, S. \& Guise, H.J. 2000. Nitrogen losses from outdoor pig farming systems. Soil Use and Management 16: 237243.

Yang, P. \& Lorimor, J. 2000. Physical and chemical analysis of beef cattle feedlot runoff before and after soil infiltration and wetland treatment. In: Moore, J. (ed.). Animal, agricultural and food processing wastes. Proceedings of the 8th international symposium. American Society of Agricultural Engineers, St. Joseph. p. 203-208. 
Vol. 11 (2002): 355-369.

\title{
SELOSTUS
}

\section{Typpi- ja fosforikuormitus emolehmien ulkotarhassa}

\author{
Jaana Uusi-Kämppä \\ MTT (Maa- ja elintarviketalouden tutkimuskeskus)
}

Nautojen kasvatusta ulkotarhoissa ja lypsylehmien ulkoiluttamista jaloittelutarhoissa harjoitetaan arviolta noin 200 maatilalla Suomessa. Tarhojen aiheuttamasta ympäristökuormituksesta kylmissä olosuhteissa on vähän tutkimustietoa. Niinpä emolehmien talviaikaisesta tarhaamisesta aiheutuvaa vesistökuormitusta alettiin tutkia MTT:n emolehmänavetalla vuonna 1997.

Emolehmiä tarhattiin neljässä metsätarhassa (975-1300 $\mathrm{m}^{2}$ ) talvikuukausina 1997-2000. Kesän emot vasikoineen viettivät laitumella. Kussakin tarhassa oli kahdeksan emolehmää. Lehmien ruokintaja makuupaikat sijaitsivat tarhojen etuosassa. Tarhojen etu- ja takaosasta sekä tarhoja ympäröivästä metsästä otettiin maanäytteitä, joista määritettiin $\mathrm{NH}_{4}^{-}$ $\mathrm{N}: \mathrm{n}, \mathrm{NO}_{3}-\mathrm{N}: \mathrm{n}$ ja helppoliukoisen fosforin $\left(\mathrm{P}_{\mathrm{AAAc}}\right)$ pitoisuudet. Lisäksi maahan kaivettiin 30-40 cm:n syvyyteen vajovesilysimetrejä, joihin kerättiin vajovettä. Lysimetreihin kertyneestä vajovedestä määritettiin $\mathrm{NH}_{4}-\mathrm{N}: \mathrm{n}, \mathrm{NO}_{3}-\mathrm{N}: n$, kokonaistypen, $\mathrm{PO}_{4}-\mathrm{P}: \mathrm{n}$ ja kokonaisfosforin pitoisuudet. Lisäksi tarhojen vieressä virtaavasta ojavedestä otettiin vesinäytteitä ravinnemäärityksiä varten v. 1998.
Suuri osa pintavalunnasta kerääntyi tarhojen etuosaan, jossa emolehmät viettivät suurimman osan ajastaan. Sekä vajovesien että maanäytteiden typpija fosforipitoisuudet olivat tarhojen etuosassa suuremmat kuin tarhojen takaosassa. Tarhoja ympäröivästä metsämaasta mitattiin alhaisimmat pitoisuudet.

Tarhojen etuosassa $0-20 \mathrm{~cm}: n$ syvyydessä oli kokeen loppuessa $\mathrm{NH}_{4}-\mathrm{N}$ :ä $55 \mathrm{mg} \mathrm{l}^{-1}, \mathrm{NO}_{3}-\mathrm{N}$ :ä $14 \mathrm{mg}$ $1^{-1}$ ja helppoliukoista fosforia $29 \mathrm{mg}^{-1}$ maata. Tarhojen ulkopuolella olevassa metsämaassa vastaavat pitoisuudet olivat $3 \mathrm{mg} \mathrm{NH}_{4}-\mathrm{N} \mathrm{ml}^{-1}, 0,1 \mathrm{mg} \mathrm{NO}_{3}-\mathrm{N}$ $\mathrm{ml}^{-1}$ ja $2 \mathrm{mg} \mathrm{P}_{\mathrm{AAAc}} \mathrm{ml}^{-1}$. Yhden metrin paksuisessa tarhan etuosan maakerroksessa oli yhden tai kahden tarhausvuoden jälkeen $410 \mathrm{~kg} \mathrm{NH}_{4}-\mathrm{N} \mathrm{ha}^{-1}$ ja $28 \mathrm{~kg}$ $\mathrm{NO}_{3}-\mathrm{N} \mathrm{ha}^{-1}$.

Vajoveden ravinnepitoisuudet olivat suuria. Kokonaisfosforipitoisuus oli 1,73-28,2 $\mathrm{mg} \mathrm{l}^{-1}$, kokonaistyppipitoisuus 206-1368 $\mathrm{mg} \mathrm{l}^{-1} \mathrm{ja} \mathrm{NH}_{4}-\mathrm{N}$-pitoisuus 123-1121 $\mathrm{mg} \mathrm{l}^{-1}$. Vastaavia typpipitoisuuksia oli mitattu Yhdysvalloissa kiinteäpohjaisen ulkotarhan valumavedestä. Maapohjaisen tarhan ravinnekuormitus voikin kasvaa suureksi, jollei tarhaa suunnitella ja hoideta asiallisesti. 